Katri-Maria Järvinen, Pasi Pyöriä, Satu Ojala, Liudmila Lipiäinen \& Tiina Saari

Tätäkin artikkelia on ollut omalta osaltaan mahdollistamassa pitkäaikainen esimiehemme ja esikuvamme Jouko Nätti. Hän ohjasi meitä kohti rekisteritutkimusta ja opetteli kanssamme soveltuvia menetelmiä. Tällä artikkelilla kunnioitamme syvästi ystävämme elämäntyötä ja muistoa.

\title{
Työurien vakaus ja taantuma: yksityisen sektorin työntekijöiden työurapolut 2007-2015
}

Abstrakti

\section{Johdanto}

Työurista on tullut yleinen talous-, yhteiskuntaja työpoliittisten keskustelujen aihe. Etenkin työurien pidentäminen on noussut työpolitiikan keskiöön (Valtioneuvoston kanslia 2017; 2019). Jotta väestön ikääntymisen kustannuk-
Tarkastelemme tutkimuksessamme yksityisissä yrityksissä vuonna 2007 työskennelleiden 30-50-vuotiaiden suomalaisten työuria vuosina 2007-2015. Analysoimme Tilastokeskuksen työntekijä-työnantaja-aineiston (FLEED-FOLK) ja siihen yhdistetyn tilinpäätöspaneelin avulla yksilö-, perhe- ja yritystekijöiden, erityisesti yritysten kannattavuuden (käyttökate), yhteyttä työuriin. Työuria mittaamme vuotuisilla työssäolokuukausilla. Ensiksi tutkimme trajektorianalyysilla, miten työurat eriytyvät erilaisiksi työurapoluiksi. Toiseksi tutkimme multinomiaalisella logistisella regressiolla, miten eri yksilö-, perhe- ja yritystekijät ennakoivat eri polkuryhmiin sijoittumista. Trajektorianalyysi tuotti kuusi erilaista työurapolkutyyppiä. Tutkimusperiodille ajoittuneesta taantumasta huolimatta neljä viidestä työntekijästä sijoittui joko vakaalle tai seurannan aikana vakautuvalle työurapolulle. Korkeampi koulutusaste yhdistyi vakaampiin urapolkuihin. Lasten syntymä eriytti voimakkaasti naisten työuria, mutta ei juurikaan miesten. Parisuhde ennusti vakaata työuraa, ja eroaminen ja yksin eläminen vaihtelevia työuria. Myös parisuhteen muodostuminen seurantajaksolla liittyi epävakaampiin työuriin. Yritystekijöistä vakain urapolku oli niillä, jotka työskentelivät kannattavuudeltaan stabiileilla toimipaikoilla. Kannattavuudeltaan vaihtelevien samoin kuin laskevien yritysten toimipaikoissa työskentelevillä oli epävakaimmat työurat. Tulostemme mukaan työurat olivat enemmistöllä vakaita myös finanssikriisin aiheuttaman taloudellisen taantuman aikana. Tulos koskee niitä yksityisen sektorin työntekijöitä, jotka olivat työssä finanssikriisiä edeltävänä vuonna 2007. 
mutta viime vuosina myönteinen kehitys on pysähtynyt (Eläketurvakeskus 2019).

Työurien pituuden ja vakauden tutkiminen edellyttää edustavien (pitkittäis)aineistojen hyödyntämistä. Lisäksi ajallisen muutoksen huomioon ottaminen on tärkeää työmarkkinoiden dynaamisen ja syklisen luonteen ymmärtämiseksi. Viimeaikaisten tutkimusten mukaan työhön liittyvä epävarmuus - kuten pätkätöiden yleistyminen tai työurien pirstoutuminen - ei yksioikoisesti luonnehdi suomalaisia työmarkkinoita, joskin ammatti-, koulutus- ja toimialakohtaiset erot voivat olla suuria (Busk ym. 2020; Peutere ym. 2017; Pyöriä 2017; Pyöriä \& Ojala 2016; Riekhoff 2018; Rokkanen \& Uusitalo 2013; Soininen 2015). Keskimäärin kotimaiset työllisyys- ja työttömyysluvut ja työsuhdetyypit näyttävät yllättävän vakailta 2010-lukua leimanneesta taantumasta huolimatta. Vaikka vuosien 2008-2009 finanssikriisin aiheuttama lama oli poikkeuksellisen syvä (Maliranta \& Hurri 2017), palkansaajien työurien vakaus ei näytä kärsineen (Peutere ym. 2017; Ojala \& Pyöriä 2016) edes syklisillä teollisuuden toimialoilla (Eurofound 2015, 63). Palkkatyön epävarmuutta suuremmaksi taantuman aiheuttamaksi ongelmaksi muodostui rakenteellinen "krooninen työttömyys" (Aho \& Mäkiaho 2016).

Tässä artikkelissa tutkimme edustavalla rekisteriaineistolla yksityisissä yrityksissä vuonna 2007 työssä olleiden suomalaispalkansaajien työuria vuosina 2007-2015. Työuraa mittaamme vuotuisina työssäolokuukausina. Hyödynnämme Tilastokeskuksen yhdistettyä työntekijä-työnantaja-aineistoa (FLEEDFOLK) ja siihen linkitettyä tilinpäätöspaneelia. Aineisto sisältää keskeisiä työuramittareita ja mahdollistaa yksilö-, yritys- ja toimipaikkatietojen yhdistämisen. Seurannan alkupiste on ajoitettu vuoteen 2007, aikaan ennen finanssikriisiä. Seuranta päättyy vuoteen 2015 , johon asti aineistomme ulottui tutkimuksen tekohetkellä.

Ensimmäinen tutkimuskysymyksemme on, millaisille työurapoluille yksityisen sektorin työntekijät sijoittuvat vuodesta 2007 alkavalla kahdeksan vuoden seurantajaksolla. Toiseksi kysymme, millä henkilö-, perhe- ja yritystekijöillä on yhteyksiä siihen, millaisille työurapoluille sijoitutaan. Aiempaan tutkimukseen nähden uutena yritystason tekijänä arvioimme yrityksen kannattavuutta. Sitä mittaamme käyttökatteella, joka kertoo yrityksen liiketoiminnan tuloksen ennen poistoja ja rahoituseriä. Olemme kiinnostuneita erityisesti yritysten kannattavuuden kehityssuunnasta ja sen yhteydestä työurien vakauteen. Jaamme yritykset kannattavuudeltaan stabiilin, vaihtelevan, kasvavan ja laskevan kehityksen ryhmiin ja katsomme, miten työurapolut näiden ryhmien mukaan eriytyvät.

Keskitymme yksityisen sektorin yrityksiin, koska aineistomme ei sisällä kattavaa tietoa valtio- ja kuntaorganisaatioiden taloudellisesta tilanteesta. Sen lisäksi julkisten organisaatioiden toiminta rahoitetaan verovaroin, eikä niiden toiminnan kannattavuutta voida käyttää samassa mielessä markkinaehtoisten muutosten indikaattorina kuin yksityisten yritysten.

\section{Työurat pitkittäistutkimuksen kohteena}

Käsitteellä työura tarkoitetaan yksilön työkokemusten ajallisesti rakentuvaa järjestystä tai jatkumoa (Collin \& Young 2000). Perinteisesti työura tai urapolku on viitannut katkeamattomaan työtehtävien jatkumoon samassa organisaatiossa. Tämä painotus on hallinnut aihetta koskevaa tutkimusta. Monet työuraa koskevat määritelmät ja teoriat ovat rakentuneet oletukselle pitkäaikaisesta työsuhteesta, joka onnistuessaan merkitsee nousujohteista urakehitystä. (Koivunen ym. 2012, 11.)

Lineaarista urakäsitystä on kritisoitu, koska työuran alkamista ja toisaalta päättymistä on aikaisempaa hankalampaa määrittää tarkasti (Kalleberg \& Mouw 2018). Nuorilla ansiotyö ja opiskelu tyypillisesti limittyvät. Myöhemmin perhevapaat, sairausjaksot, jatkokoulutus ja työttömyys aiheuttavat katkoja ansiotyöhön, ja toisaalta työntekijät vaihtavat työ- 
paikkoja ja ammatteja uransa kuluessa. Eläkkeellekään ei aina siirrytä suoraan työelämästä. Suomessa noin 40 prosenttia työllisistä siirtyy eläkkeelle työttömyyden, sairausjaksojen tai muiden välivaiheiden kautta. (Myrskylä 2014; Riekhoff 2018.) Tässä tutkimuksessa emme kuitenkaan erittele urasiirtymiä tai -katkeamia, joskin tilastollisessa mallissamme kontrolloimme seuranta-aikana mahdollisesti muuttuvia tekijöitä, kuten lasten syntymät, toimipaikan vaihtumiset, päätoimisen opiskelun ja työkyvyttömyyseläkkeelle siirtymiset. Keskitymme työurien vakauden tarkasteluun, joka on tyypillisin aiemman tutkimuksen näkökulma (Bachmann \& Felder 2018; Kalleberg \& Mouw 2018). Koska keskitymme työurien vakauteen, emme tutki myöskään työuralla tapahtuvia laadullisia muutoksia, kuten työuralla etenemistä (vrt. Gerber ym. 2009).

Aiempien kotimaisten rekisteritutkimusten perusteella tiedetään, että työoloilla ja niiden kehittämisellä voidaan vaikuttaa myönteisesti työurien vakauteen ja eläkkeelle siirtymiseen (Järnefelt 2016). Myös työurien alkua on kartoitettu pitkittäisasetelmalla. Ojala ja Pyöriä (2016) tutkivat 15-30-vuotiaiden työurien vakautta kolmella vuosikymmenellä Tilastokeskuksen työolotutkimuksiin yhdistetyllä rekisteriseurannalla (1984-2011). Tutkimus osoitti, että nuorten työurat ovat 2000-luvulle tultaessa vakautuneet, kun työuria tarkasteltiin vuotuisina työkuukausien keskiarvoina. Vuosien 2008-2011 seurantajakson aikana nuorten palkansaajien suhteellinen asema jopa parani - finanssikriisistä huolimatta - verrattuna kaikkien palkansaajien työkuukausien keskiarvoon.

Työurien pituuden ja vakauden ohella suomalaisilla pitkittäisaineistoilla on tutkittu työmarkkinoille kiinnittymistä. Tutkimuksissa on muun muassa käsitelty irtisanottujen työntekijöiden uudelleen työllistymistä (Jolkkonen ym. 2014), äitien työmarkkina-asemaa vanhempainvapaan jälkeen (Peutere ym. 2015; Peutere 2019) sekä korkeasti koulutettujen työurapolkuja ja työttömyyttä (Asplund \& Vanhala 2016; Saloniemi ym. 2013). Edellä mainituissa tutkimuksissa on tarkasteltu rajattuja työntekijäryhmiä eikä suomalaisten työmarkkinoiden laajempaa kuvaa, kuten tässä artikkelissa.

\section{Yrityksen taloudellinen tilanne ja työurat}

Joidenkin rekisteriaineistojen etuna on mahdollisuus yhdistää työntekijä-, yritys- ja toimipaikkatason tietoja (Abowd \& Kramarz 1999). Tämänkaltaisia yhdistettyjä pitkittäisaineistoja, kuten FLEED-FOLK, on käytetty aiemmin etenkin taloustieteissä. FLEED-aineistolla on tutkittu esimerkiksi henkilöstön ikärakenteen muutoksen ja yrityksen tuottavuuden välistä yhteyttä (Ilmakunnas \& Maliranta 2016), työpaikkojen katoamisen ja työhyvinvoinnin dynamiikkaa (Böckerman ym. 2011) sekä urasiirtymiä palkkatyöstä yrittäjyyteen (Hyytinen \& Maliranta 2008).

Liikevaihtoa on käytetty paljon tutkimuksissa yrityksen taloudellisen tilanteen ja kasvun indikaattorina (Davidsson \& Wiklund 2006, 52). Liikevaihdon ohella yrityksen kasvua on mitattu henkilöstömäärän muutoksella (Peltola \& Soininen 2003). Tyypillisesti liikevaihto kasvukriteerinä tuottaa selvästi suuremman joukon kasvuyrityksiä kuin henkilöstömäärään keskittyvät arviot (Kiljunen \& Rikama 2011). Kasvuyrityksestä puhuttaessa viitataan tutkimuksesta riippuen joko liikevaihdon tai työntekijämäärän kasvuun (Maliranta \& Hurri 2017) tai näiden molempien yhteisvaikutukseen (Tornikoski ym. 2011).

Jolkkosen ja kumppaneiden (2014) tutkimuksessa tarkasteltiin FLEED-aineistolla toimipaikan lakkauttamisen seurauksena työpaikkansa menettäneiden uudelleen kiinnittymistä työmarkkinoille. Seitsemän vuoden seurannassa vuonna 2003 työpaikkansa menettäneistä huomattavan suuri osuus (83\%) kiinnittyi uudelleen vahvasti työmarkkinoille. Tuolloin työmarkkinoille uudelleen kiinnittyminen oli vakaampaa kuin vuonna 1997 työpaikkansa menettäneillä. Heikointa kiinnittyminen oli lamavuonna 1992 työpaikkansa 
menettäneillä. Vaikka alueelliset ja toimialakohtaiset erot voivat olla huomattavia, suomalaispalkansaajien työurien vakaus näyttää aiempien tutkimusten perusteella keskimäärin vahvistuneen, minkä lisäksi työpaikkansa menettäneillä on jopa yllättävän hyvät mahdollisuudet löytää uusi työpaikka.

Aiemmassa (Peutere ym. 2017) FLEED-aineistoa soveltaneessa tarkastelussa yksityisen sektorin palkansaajien työuravaikutuksia tutkittiin luokittelemalla toimipaikkatasoinen tieto liikevaihdosta neljään tyyppiin. Stabiilin, vaihtelevan, kasvavan ja laskevan liikevaihtokehityksen toimipaikkoja tarkasteltiin kolmena ajanjaksona vuodesta 1990 alkaen niin, että jokaisen liikevaihtotyypin toimipaikoissa työskentelevien työuria tarkasteltiin erikseen liikevaihtotyypeittäin ja tutkittiin, millaisia työuraryhmiä aineistosta muodostuu. Tulosten mukaan vakaalla työuralla eli keskimäärin 12 kuukautta vuosittain läpi seurantaajan työskennelleiden osuus kasvoi vuosien 1990-1995 seurantajaksolta vuosien 20072012 ajanjaksolle, mikä on ymmärrettävää, kun ottaa huomioon 1990-luvun laman poikkeuksellisuuden.

Tässä artikkelissa olemme kuitenkin kiinnostuneita liiketoiminnan kannattavuuden kehityksestä emmekä toiminnan volyymistä, jota liikevaihto ilmentää. Tiedossamme ei ole aiempia tutkimuksia, joissa olisi selvitetty työurien vakautta yritysten kannattavuuden näkökulmasta. Oletamme, että yrityksen kannattavuuden myönteinen kehitys vaikuttaisi myönteisesti myös sen henkilöstön työuriin.

\section{Finanssikriisi ja taantuma tutkimuksen kontekstina}

Tutkimuksemme kontekstina on vuoden 2008 lopulla Suomeen rantautunut finanssikriisi ja sitä seurannut taantuma. Analyysimme lähtöpisteessä vuonna 2007 elettiin pitkään jatkuneen nousukauden huipulla, kunnes vuoden 2008 viimeisellä neljänneksellä talouskasvu pysähtyi. Vuonna 2009 bruttokansantuote su- pistui yli kahdeksan prosenttia. Seuraavana kahtena vuonna talous kasvoi maltillisesti taantuakseen jälleen vuosina 2012-2014, kunnes taantuma taittui vuonna 2015. Tämän kaksoistaantumaksi kutsutun ajanjakson väliin jääneet kaksi parempaa vuotta eivät riittäneet kompensoimaan vuonna 2009 menetettyä kasvua. (SVT 2018.)

Finanssikriisin taustalla oli sekä globaaleja että Suomen sisäisiä ongelmia. Yhdysvalloista alkunsa saanut rahoitusmarkkinoiden epävarmuus laajeni 2010-luvun taitteessa euroalueen vakautta horjuttaneeksi velkakriisiksi, joka heijastui nopeasti vientiyritystemme toimintaedellytyksiin. Taantuma vaikutti Suomen vientiin voimakkaammin kuin moniin muihin OECD-maihin (Hetemäki 2010, 15). Esimerkiksi metsäteollisuuden tuotteiden kysyntä laski, samalla kun vuoden 2008 palkankorotukset heikensivät kilpailukykyä. Lisäksi Nokia-klusteri ja sähkötekninen teollisuus ajautuivat kriisiin. Ilman sähköteknisen teollisuuden vaikutusta Suomen bruttokansantuote olisi vuonna 2009 supistunut kahdeksan prosentin sijasta 5-6 prosenttia, kun se OECD-maissa laski keskimäärin nelisen prosenttia (Maliranta ym. 2011).

Taloussokkien vaarana on, että suhdanneluonteiset työmarkkinoiden ongelmat muuttuvat rakenteellisiksi, eivätkä ne korjaudu suhdanteiden kohentuessa (Ilmakunnas 2010, 45). Kun 1990-luvun laman jälkeen työllisyyskehitys oli ollut vakaata, käänsi vuonna 2008 alkanut finanssikriisi työttömyyden kasvuun ensimmäisen kerran vuoden 1994 jälkeen. Vuoden 2007 noususuhdanteessa työttömyysaste oli 6,9 prosenttia. Työttömyys alkoi kasvaa vuonna 2009, kunnes se taittui vuonna 2011 kääntyäkseen jälleen kasvuun vuonna 2013. Korkeimmillaan työttömyysaste oli 9,4 prosenttia tutkimuksemme seuranta-ajan lopussa vuonna 2015.

Yksityisen sektorin työllisten määrä oli korkeimmillaan 1830000 henkilöä vuonna 2008, minkä jälkeen määrä kääntyi laskuun ja oli 1759000 henkilöä vuonna 2015. Yksityisellä sektorilla työskentelevien pal- 
kansaajien määrä oli seurantamme alussa 1517000 henkilöä. Korkeimmillaan se oli vuonna 2008 (1532000), minkä jälkeen määrä sahasi laskusuuntaisesti ja oli seurannan lopussa 1414000 henkilöä. (Tilastokeskus 2019.) Tutkimuksemme tarkasteluväliä luonnehtii myös voimakas työikäisen väestön määrän väheneminen (Kauhanen 2017, 154).

Yritysten toiminnassa finanssikriisi ilmeni tuotannon laskuna ja työn tarjonnan vähenemisenä, kun työpaikkojen tuhoutumisaste (eli toimipaikoilla tapahtuneiden työntekijöiden vähennyksien määrä) nousi (Ilmakunnas \& Maliranta 2011, 21). Kaiken kaikkiaan finanssikriisistä alkanut talouden alavire kesti lähes vuosikymmenen verran eli koko seurantajaksomme ajan. Aiemman kotimaisen (Ojala \& Pyöriä 2016; Pyöriä ym. 2017) ja kansainvälisen (Bachmann \& Felder 2018; Eurofound 2015) tutkimuksen perusteella kuitenkin oletamme, ettei taantuma ole keskimäärin heikentänyt työurien vakautta. Kun matalasuhdanteessa työpaikkoja on aiempaa vähemmän ja kilpailu niistä kovenee, työvoiman liikkuvuus yleensä heikkenee (Aho ym. 2009, 23; Busk ym. 2020).

\section{Aineisto ja menetelmät}

\section{Aineisto}

Perustamme tutkimuksemme Tilastokeskuksen yhdistettyyn FOLK työntekijä-työnantajaaineistoon, joka tunnetaan aiemmassa tutkimuksessa nimellä FLEED (Finnish Longitudinal Employer-Employee Data). Käytössämme on kokonaisaineisto, joka sisältää tiedot kaikista Manner-Suomessa asuneista 15-70-vuotiaista henkilöistä (n. 3,6 milj. henkilöä vuosittain) alkaen vuodesta 1988. Henkilöitä on seurattu yli ajan eli heistä on tietoja kaikilta niiltä vuosilta, jolloin henkilö on elossa, 15-70-vuotias ja asuu Suomessa. FLEED-FOLK on koostettu muun muassa Väestörekisterikeskuksen väestötietojärjestelmän, työ- ja elinkeinoministeriön työnhakijarekisterin sekä toimipaikkarekisterin tie- doista. Tätä tutkimusta varten FLEED-FOLKaineistoon on linkitetty tilinpäätöspaneeli, joka sisältää tietoja muun muassa yritysten tuloksesta, kuten käyttökatteesta. Tilinpäätöspaneeli ei sisällä kattavasti pienyritysten tietoja, minkä vuoksi joudumme rajaamaan alle 10 henkilöä työllistävät yritykset pois. Myös lähtöpistevuoden lopulla yrittäjiksi kirjatut henkilöt jätettiin pois ja näin ollen tarkastelumme koskee vuonna 2007 yksityisen sektorin vähintään 10 hengen yrityksissä työskennelleitä palkansaajia.

Aloitimme aineiston rakentamisen yritystasolta käyttökatetiedon saatavuuden perusteella. Muodostimme yrityksen kannattavuutta kuvaavan muuttujan käyttämällä tilinpäätöspaneelin tietoa yrityksen käyttökatteesta kolmelta vuodelta (2006-2008). Mukaan otimme näissä yrityksissä työssä olleet henkilöt, jotka edustivat lähtöpistevuonna 2007 30-50-vuotiaita yksityisen sektorin työntekijöitä. Rajasimme tarkastelun vähintään 30-vuotiaisiin, jolloin korkeakouluopinnoista on pääosin siirrytty työelämään, ja toisaalta korkeintaan 50-vuotiaisiin, jotta seuranta-aika jäisi virallisen ja useimmiten toteutuvan eläkeiän alle (Myrskylä 2014). Toimme yritystasolta tilinpäätöspaneelin tiedot näille henkilöille ja poimimme henkilöistä kahden prosentin satunnaisotoksen seurannan lähtöpisteessä. Tämä oli välttämätöntä trajektorianalyysien vaatiman suuren laskentatehon vuoksi. Näin saatiin aineisto, jossa on 9149 henkilön tiedot. He työskentelivät 4054 eri yrityksessä.

FLEED-FOLK sisältää laajasti henkilöiden taustatietoja, kuten tiedon sukupuolesta, iästä, perhetilanteesta, työsuhteista, työttömyysjaksoista, työkyvyttömyyseläkkeestä sekä koulutuksesta ja päätoimisesta opiskelusta. Yksilötietoihin on lisätty työnantajan yritystunniste ja toimipaikkatunniste sekä toimipaikkarekisteristä saatu tieto toimipaikan henkilöstömäärästä ja toimialasta (Tilastokeskus 2017b). Yksilötiedot on yhdistetty yritystä ja toimipaikkaa koskeviin rekisteritietoihin henkilön vuoden lopussa voimassa olevan työsuhteen perusteella (Tilastokeskus 2017a). Kaikki ai- 
neiston henkilö-, toimipaikka- ja yritystunnisteet ovat kryptattuja ja siten täysin anonymisoituja. Aineistoa käytimme suojatulla verkkoyhteydellä Tilastokeskuksen Fiona-etäkäyttöpalvelussa. Aineiston käytölle tunnusomaista on, että tutkijan on itse muokattava rekisterin raakadatasta omaan tutkimukseensa soveltuvat muuttujat (Soininen 2015, 109). Kuvaamme seuraavassa tutkimuksemme mittarit.

Selitettävä muuttujamme on työssäolokuukaudet. Poimimme aineistoon valituille 9149 henkilölle vuosille 2007-2015 vuosittaisten työssäolokuukausien lukumäärän. Muuttuja sai arvon nolla, jos henkilöllä ei ollut merkittyä työssäoloa kyseisenä vuonna. Niissä tapauksissa, joissa henkilö oli poistunut aineistosta (kuollut, ulkomailla), merkitsimme työssäolokuukausia koskevan tiedon puuttuvaksi.

Yksilö- ja perhetekijät. Tarkastelemme keskeisimpien henkilötekijöiden yhteyksiä työuriin. Huomioimme ensinnäkin sukupuolen ja iän (jatkuvana muuttujana). Lisäksi tarkastelussa on koulutustaso (ei perusasteen jälkeistä tutkintoa, vähintään keskiasteen koulutus, alin tai alempi korkeakoulututkinto, ylempi korkeakoulututkinto yhdistettynä tutkijakoulutuksen kanssa), samoin kuin se, mikäli henkilö suorittaa uuden tutkinnon jonakin seurantavuonna (kyllä, ei). Perhetekijöistä tutkimme parisuhteen muutoksia ja lasten syntymän yhteyksiä työuriin. Lapsista huomioimme lähtötilanteen tiedon henkilön biologisten lasten lukumäärästä vuotta ennen seurannan alkua (vuonna 2006). Toiseksi huomioimme seuranta-aikana syntyvät lapset eri vaiheissa (syntymä alussa vuosina 2007-2010 tai jälkipuoliskolla vuosina 2011-2015). Parisuhdetiedon muodostimme kotitalouden perhetyyppi- ja perheasemamuuttujien perusteella neliluokkaiseksi siten, että vertasimme seurannan ensimmäistä ja viimeistä vuotta (parisuhde koko ajan, eroaa seurannan aikana, asuu yksin koko ajan, asuu aluksi yksin ja on lopussa parisuhteessa).

Yritystekijät. Aiempaan tutkimukseen nähden uutena yritystason tarkasteltavana seik- kana tutkimme yrityksen kannattavuutta ja sen mittarina (korjattua) käyttökatetta. Käyttökate kuvaa sitä rahamäärää, joka liikevaihdosta jää, kun siitä on vähennetty liiketoiminnan kulut (Yritystutkimus 2017, 63-64). Luokittelimme käyttökatteen kolmen vuoden kehityksen perusteella stabiilin, vaihtelevan, kasvavan ja laskevan kannattavuuden ryhmiin. Käyttökatteen muutoksen kriteeriksi asetimme yli 30 prosentin vuosittaisen kasvun tai laskun (vrt. Soininen 2015, 109). Stabiilin kannattavuuden yrityksiksi määrittelimme ne, joissa vuosimuutokset jäivät tätä alhaisemmiksi. Kasvavaan kannattavuuteen sisältyy 30 prosentin käyttökatteen lisäys vähintään yhtenä määrittelyvuonna, laskevaan taas vastaava muutos alaspäin; vaihtelevassa kannattavuudessa 30 prosentin vuosimuutos ehtii tapahtua kahteen suuntaan.

Yritysten kannattavuuden määrittelimme ensin kolmelta eri ajanjaksolta, koska valittu ajanjakso saattaa vaikuttaa tuloksiin (Maliranta 2008). Teimme luokittelut vuosille ajalta ennen seurantaa (2005-2007), sekä vuosille 2006-2008 ja 2007-2009. Stabiilin ja vaihtelevan kannattavuuden yrityksiä oli kaikilla ajanjaksoilla noin 18-20 prosenttia (stabiili kannattavuus) ja 26-27 prosenttia (vaihteleva kannattavuus). 2005-2007 kasvavan kannattavuuden yrityksiksi määrittyi 30 prosenttia yrityksistä mutta 2007-2009 vain 23 prosenttia. Vastaavasti laskevan kannattavuuden yrityksiä oli 2005-2007 26 prosenttia ja 2007-2009 31 prosenttia yrityksistä. Vertasimme tämän uuden mittarin tuloksia myös liikevaihtomittariin ja totesimme, että käyttökatteen yhteydet työuriin ovat jonkin verran voimakkaammat kuin liikevaihdon. Selitysasteosuudet olivat kuitenkin kauttaaltaan rajalliset ja ne vaihtelivat $0.2-0.4$ prosentin välillä. Valitsimme käyttöömme vahvimmin työurapolkuryhmiin yhteydessä olleen, vuosien 2006-2008 käyttökatemäärittelyn. Määrittelyjakso saattaa sisältää jo vuoden 2008 lopun osalta joidenkin yritysten ajautumisen talouskriisitilanteeseen, mutta tämän vaikutus jäänee kuitenkin vähäiseksi. Mittari 
koskee siis kolmea vuotta, ja henkilöseuranta aloitetaan keskimmäisestä vuodesta. Tuolloin henkilöstö on suurimmaksi osaksi saman yrityksen palveluksessa ja oletamme, että käyttökate yritystasolla voi vaikuttaa myös henkilöstön tuleviin työuriin.

Tarkastelimme yritystasolla myös toimialan (vuonna 2007), henkilöstömäärän (vuonna 2007) sekä henkilön toimipaikkavaihdoksen (v. 2007 verrattuna vuoteen 2009) yhteyksiä työuriin. Toimipaikan henkilöstömäärän jaoimme kolmanneksiin sen perusteella, miten suuri osuus mukana olevista työntekijöistä niihin sijoittui (10-99, 100-799, 800-1746 henkeä). Toimipaikan toimialan huomioimme kahdeksanluokkaisella muuttujalla: (a) rahoitustoiminta, kiinteistö-, vuokraus- ja tutkimuspalvelut, liike-elämän palvelut; (b) teollisuus; (c) rakentaminen, sähkö-, kaasu- ja vesihuolto; (d) tukku- ja vähittäiskauppa, korjaus; (e) majoitus ja ravitsemus; (f) kuljetus, varastointi, tietoliikenne; (g) yksityiset sosiaali-, terveys-, koulutus- ja henkilökohtaiset palvelut; ja (h) muut palvelut, taide ja järjestöt sekä alkutuotanto. Työntekijän toimipaikan vaihtamista kuvaa muuttuja "toimipaikka vaihtuu" (kyllä, ei). Toimipaikan vaihtumisen otimme huomioon seurannan alussa ajanjaksolla 2007-2009.

Kontrollimuuttujat. Lisäksi kontrolloimme tekijöitä, joiden tiedetään olevan yhteydessä palkansaajien työuriin (esim. Järnefelt 2016). Huomioimme päätoimisen opiskelun seuranta-aikana, osa- tai kokoaikaisella työkyvyttömyyseläkkeellä olemisen sekä seurantaa edeltävän vuoden 2006 tiedon siitä, onko henkilö ollut työttömänä.

\section{Menetelmät}

Tutkimme työurien vakautta ja eriytymistä (heterogeenisuutta) aineistolähtöisellä trajektori- eli kehityspolkuanalyysillä (Nagin 1999). Trajektorianalyysi on sekoitettujen jakaumien teorian sovellus, joka perustuu suurimman uskottavuuden menetelmään. Trajektorianalyysi huomioi aineiston eri osapopulaatioiden mahdollisesti erilaiset kehityspolut, toisin kuin useat muut pitkittäisaineistojen analysointimenetelmät (Nagin 2005). Käsitteellä työurapolku (vrt. Saloniemi ym. 2013) viittaamme trajektorianalyysillä tuotettuihin työurien kehityssuuntia kuvaaviin käyriin. Trajektorianalyysi (Nagin 2005) eriyttää henkilöiden työurista kehitykseltään erityyppisiä ryhmiä. Menetelmällä tarkastellaan kunkin yksittäisen työntekijän työuraa, ja tämän tiedon avulla etsitään useiden yksilöiden urapolkujen muotoa kuvaavia trajektoriryhmiä. Näin esimerkiksi vakautuvalla, heikkenevällä tai vakaana pysyvällä työuralla olevat henkilöt lajitellaan omiin trajektoriryhmiin ja jatkossa niitä voidaan tutkia omina ryhminään.

Aloitimme trajektorianalyysin valitsemalla todennäköisyysjakauman selittävälle muuttujalle. Vuotuisten työssäolokuukausien lukumäärää mittaava muuttuja on voimakkaasti vino, koska suurimmalla osalla henkilöistä työkuukausia on 12. Analyysia varten käänsimme työssäolomuuttujan vähentämällä luvusta 12 muuttujan saaman arvon, jolloin saatiin "työstäpoissaolomuuttuja", jonka jakaumassa on piikki nollassa. Selitettävän muuttujan todennäköisyysjakaumaksi valitsimme Poisson-jakauman ja malliin valitsimme toisen asteen käyrän, joka sopi aineistoon informaatiokriteereiden AIC ja BIC vuoksi paremmin kuin lineaarinen käyrä. Kokeilimme aineistoon yhdestä kymmeneen trajektoriryhmän ratkaisua, joista jokaista ajoa toistettiin 10 kertaa. Trajektoriryhmien lukumäärää valittaessa käytimme BIC-arvoa, joka on Tolvasen (2007) mukaan parempi kuin AIC tässä tapauksessa. BIC-informaatiokriteerin arvo laski arvosta 377029 yhden ryhmän ratkaisussa arvoon 147042 kuuden ryhmän ratkaisussa.

Trajektorianalyysin lopputulemana kuusi trajektoriryhmää oli tilastollisesti paras aineistoon sopiva ratkaisu. Tilastollista mallia estimoitaessa laskimme jokaiselle henkilölle posterioritodennäköisyydet kuulua jokaiseen trajektoriryhmään. Henkilöt sijoitimme trajektoriryhmään suurimman posterioritodennä- 
köisyyden mukaan, ja huomioimme posterioritodennäköisyydet jatkoanalyysissa. Muodostetuille trajektoriryhmille laskimme havaituista työssäolokuukausista keskiarvot kaikkina seurantavuosina ja piirsimme niistä keskiarvokäyrät (työurapolut), jotka kuvaavat trajektoriryhmien keskimääräistä työssäolokuukausien kehitystä.

Työurapolkujen ja yritysten kannattavuuden yhteyttä tutkimme multinomiaalisella logistisella regressioanalyysilla, joka mahdollistaa useampiluokkaisen työurapolkumuuttujan käyttämisen selitettävänä muuttujana sekä useiden taustamuuttujien kontrolloinnin. Multinomiaaliset logistiset regressiomallit aloitimme perusmallista, jossa selittäjänä olivat ensin vain kontrollimuuttujat (malli 0). Laajensimme perusmallia lisäämällä ensimmäisellä askeleella perhe- ja yksilötekijät (malli 1), ja toisella askeleella yritysmuuttujat (malli 2). Vertaamme selitysasteen muutoksia näissä malleissa, jotta voisimme arvioida, ovatko yksilö- ja perhe- vai yritystason ennustajat työurien kehityksen kannalta merkittävämpiä. Viimeisessä mallissa 3, jonka tulokset esitämme taulukossa 2, mukana ovat kaikki ennustajat. Regressiomallissa tulki- taan muuttujien luokkien ehdollisia riskisuhteita (relative risk ratio RRR) suhteessa vertailukategoriaksi asetettuun ryhmään. Kun RRR on alle yhden, riski sijoittua tarkasteltavaan työurapolkuryhmään on pienempi kuin vertailuryhmällä. Vastaavasti riskisuhteen ollessa yli yhden kyseiselle työurapolulle sijoittuminen on yleisempää kuin vertailuryhmään kuuluvilla. Aineiston muuttujia käsittelimme ja analysoimme ohjelmistoilla Stata ja R.

\section{Tulokset}

Yksityisen sektorin työntekijöiden työurapolut

Tarkastelemme seuraavassa yksityisen sektorin palkansaajien työssäolokuukausiin perustuvia työurapolkuja vuosilta 2007-2015. Trajektorianalyysin tulokset esitämme kuviossa 1 . Trajektorianalyysi tuotti kuusi työurapolkuja kuvaavaa trajektoriryhmää, jotka nimesimme työssäolokuukausien keskiarvokäyräkuvaajien perusteella vakaan, nopeasti vakautuvan, hitaasti vakautuvan, hitaasti heikkenevän, heikkenevän ja nopeasti heikkenevän työuran poluiksi.

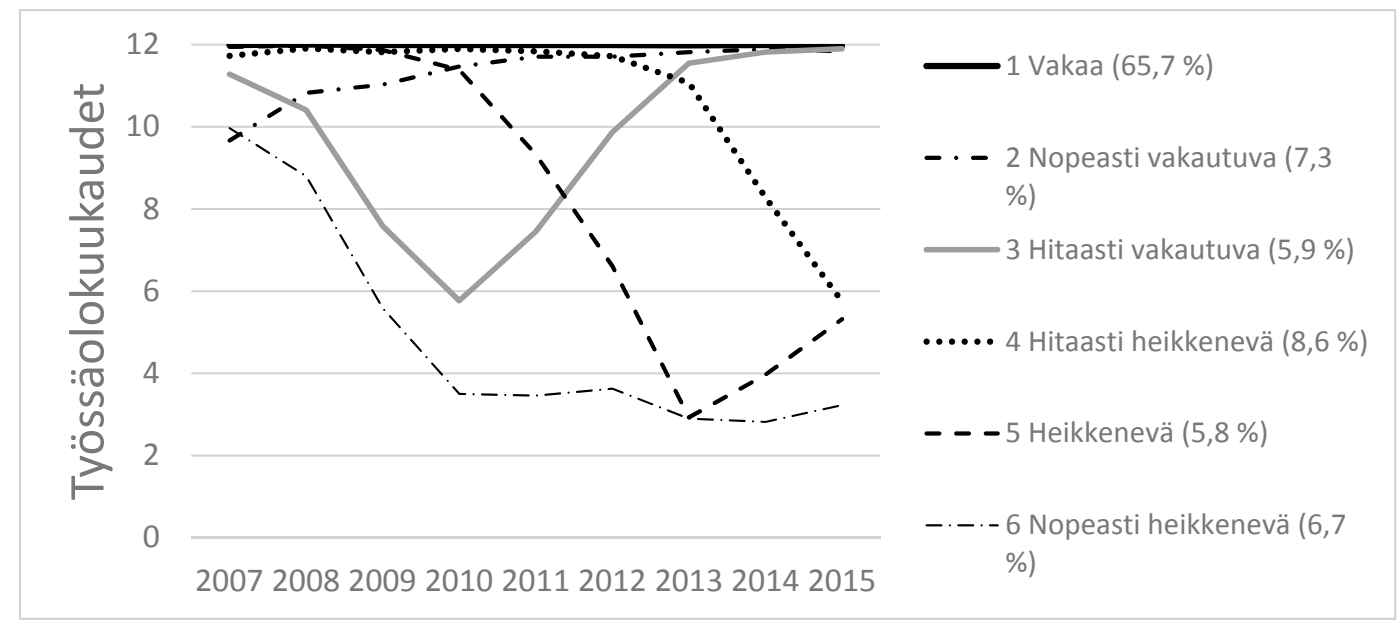

Kuvio 1. Vuoden 2007 yksityisen sektorin työntekijöiden sijoittuminen työurapoluille 2007-2015 ( $n=9149)$ 
Vakaalle työurapolulle sijoittui 66 prosenttia yksityisen sektorin palkansaajina vuonna 2007 olleista työntekijöistä. Toisin sanoen kaksi kolmasosaa työntekijöistä oli koko seuranta-ajan töissä keskimäärin 12 kuukautta vuodessa. Seurannan kuluessa vakautuvilla työurapoluilla eli nopeasti ja hitaasti vahvistuvalla uralla työskentelevien osuudet olivat $7 \mathrm{ja}$ 6 prosenttia. Nopeasti vakautuvalle työurapolulle sijoittuneiden ura vakautui hiljalleen seurannan puoliväliin eli vuoden 2011 loppuun mennessä siten, että seurannan jälkimmäisellä puoliskolla keskimääräinen työssäolokuukausien lukumäärä oli 12; hitaasti vakautuvalle polulle sijoittuneiden työura vakautui seurannan loppuun mennessä. Hitaasti vakautuvaa työurapolkua kuitenkin luonnehti myös se, että tähän ryhmään kuuluvien keskimääräiset työssäolokuukaudet vähenivät seurannan alkujaksolla ennen vuoden 2010 lopulla tapahtunutta nousujohteista käännettä.

Trajektorianalyysi tuotti myös kolme heikkenevien työurapolkujen ryhmää. Näistä suurin oli hitaasti heikkenevä työurapolku runsaan kahdeksan prosentin osuudella. Heikkenevälle ja nopeasti heikkenevälle työurapolulle sijoittui 6 ja 7 prosenttia palkansaajista. Hitaasti heikkenevällä ja heikkenevällä työurapolulla työskentelevillä oli vielä seurannan alussa lähes 12 työssäolokuukautta, mutta seurannan aikana heidän keskimääräinen työssäolokuukausien määränsä laski olennaisesti ja päätyi noin kuuteen kuukauteen vuonna 2015. Nopeasti heikkenevällä työurapolulla työskentelevien tilanne poikkesi tästä. Tähän ryhmään sijoittuneet työskentelivät seurannan alussa keskimäärin kymmenen kuukautta vuodessa, kunnes parin ensimmäisen seurantavuoden jälkeen keskimääräisten työssäolokuukausien määrä laski pysyvästi alle neljään kuukauteen.

Kaikkiaan kaksi kolmasosaa vuoden 2007 yksityisen sektorin palkansaajista sijoittui vuosina 2007-2015 vakaalle työurapolulle eli he olivat keskeytyksettä palkkatyössä. Kun laskemme mukaan vakaille ja vakautuville urapoluille sijoittuneet, seuranta-ajan loppuun mennessä lähes neljä viidesosaa työntekijöistä oli keskimäärin 12 kuukautta työssä. Viidennes työntekijöistä sijoittui heikentyville työurapoluille.

\section{Yksilö-ja perhetekijöiden yhteydet työuriin}

Esitämme seuraavaksi kahdessa taulukossa, miten eri yksilö- ja perhetekijät sekä toisaalta yrityksiä kuvaavat seikat ennakoivat vuonna 2007 yksityisellä sektorilla työssä olleiden työntekijöiden tulevia työurapolkuja. Taulukko 1 kokoaa ristiintaulukoimalla eri tekijöiden yhteydet työurapolkuryhmiin, ja taulukossa 2 esitämme multinomiaalisen regressiomallin viimeisen mallin tulokset. Monimuuttujamallin vertailuryhmänä on vakaa työurapolku, jolle valtaosa aineistomme palkansaajista sijoittui trajektorianalyysin perusteella: vertaamme viidellä epävakaammalla (sekä vakautuvilla että heikkenevillä) työurapoluilla työskenteleviä vakaalle polulle sijoittuneisiin.

Taulukon 2 alle olemme koonneet eri askelien selitysosuuksien vaihtelut: voimakkaimmat yhteydet työuriin muodostuivat ennakoidusti kontrollitekijöistä eli siitä, mikäli henkilöt opiskelivat päätoimisesti, päätyivät työkyvyttömyyseläkkeelle tai olivat olleet ennen seurantaa työttöminä ( 0 -mallin selitysaste 14 prosenttia). Aiemman työttömyyden linkittyminen epävakaisiin työurapolkuryhmiin (ks. taulukko 1) kertoo heikon työmarkkina-aseman toistumisesta ja kasautumisesta yhä uudelleen samoille henkilöille. Mallin 1 yksilö- ja perhetekijät nostivat selitysastetta 17 prosenttiin kontrollitekijöihin nähden, kun taas mallin 2 yritystekijät 16 prosenttiin. Yhteensä kaikki tekijät ennustivat työurapoluille sijoittumista 19 prosentin verran (taulukko 2, malli 3), mitä voi pitää kohtalaisena tuloksena.

Voimakkaimmin työurapolkuihin yhdistyivät lasten syntymät - mutta vain naisilla. Lapsen syntymä -muuttujat eivät itsenäisesti ennakoineet työurapolkujen eriytymistä. Tämä koskee miehiä (taulukko 2), koska yhdysvaikutustermi lasten syntymien ja sukupuolen 
Taulukko 1. Vuoden 2007 yksityisen sektorin työntekijöiden sijoittuminen työuraryhmiin (2007-2015) yksilö- ja perhe- sekä yritys- ja kontrollitekijöittäin, \%

\begin{tabular}{|c|c|c|c|c|c|c|c|}
\hline & Vakaa työura & $\begin{array}{l}\text { Nopeasti } \\
\text { vakautuva } \\
\text { työura }\end{array}$ & $\begin{array}{l}\text { Hitaasti } \\
\text { vakautuva } \\
\text { työura }\end{array}$ & $\begin{array}{l}\text { Hitaasti } \\
\text { heikkenevä } \\
\text { työura }\end{array}$ & $\begin{array}{l}\text { Heikkenevä } \\
\text { työura }\end{array}$ & $\begin{array}{l}\text { Nopeasti } \\
\text { heikkenevä } \\
\text { työura }\end{array}$ & Yht. \\
\hline \multicolumn{8}{|l|}{ Sukupuoli } \\
\hline Miehiä (n=5759) & 69 & 6 & 5 & 8 & 5 & 7 & 100 \\
\hline Naisia $(n=3390)$ & 63 & 9 & 7 & 9 & 6 & 7 & 101 \\
\hline \multicolumn{8}{|l|}{ Koulutustaso } \\
\hline Perusaste $(n=1252)$ & 57 & 7 & 7 & 9 & 7 & 13 & 100 \\
\hline Ammattiaste $(n=4268)$ & 65 & 7 & 6 & 9 & 6 & 7 & 100 \\
\hline Alin, alempi ka ( $n=2688)$ & 72 & 7 & 5 & 8 & 5 & 4 & 101 \\
\hline Ylempi ka, tutkija ( $n=941)$ & 69 & 8 & 6 & 8 & 5 & 4 & 101 \\
\hline \multicolumn{8}{|l|}{ Uusi tutkinto 2007-2015 } \\
\hline $\mathrm{Ei}(\mathrm{n}=8149)$ & 68 & 7 & 5 & 9 & 5 & 6 & 100 \\
\hline Kyllä (n=1000) & 53 & 9 & 13 & 7 & 9 & 10 & 101 \\
\hline \multicolumn{8}{|l|}{ Ikä } \\
\hline Keskiarvo (keskihajonta) & $40(.08)$ & $38(.23)$ & $39(.25)$ & $40(.22)$ & $40(.27)$ & $40(.26)$ & $40(.06)$ \\
\hline \multicolumn{8}{|l|}{ Lasten lukumäärä v. 2006} \\
\hline $0(n=1607)$ & 64 & 6 & 6 & 10 & 6 & 8 & 100 \\
\hline $1-2(n=4598)$ & 68 & 7 & 6 & 9 & 6 & 5 & 101 \\
\hline $3+(n=2944)$ & 63 & 8 & 6 & 8 & 6 & 9 & 100 \\
\hline \multicolumn{8}{|l|}{ Lapsen syntymä v. 2007-2010 } \\
\hline Ei synny $(n=7710)$ & 67 & 7 & 5 & 8 & 6 & 7 & 100 \\
\hline Syntyy (n=1439) & 63 & 8 & 9 & 8 & 5 & 5 & 98 \\
\hline \multicolumn{8}{|l|}{ Lapsen syntymä v. 2011-2015 } \\
\hline Ei synny $(n=8313)$ & 67 & 7 & 6 & 8 & 6 & 7 & 101 \\
\hline Syntyy $(n=836)$ & 63 & 7 & 8 & 10 & 6 & 6 & 100 \\
\hline \multicolumn{8}{|l|}{ Parisuhde } \\
\hline Kyllä, koko ajan $(n=5313)$ & 71 & 7 & 5 & 8 & 5 & 4 & 100 \\
\hline Alussa, eroaa ( $n=1427)$ & 60 & 8 & 6 & 10 & 6 & 9 & 100 \\
\hline Ei koko aikana $(n=1464)$ & 60 & 6 & 5 & 9 & 7 & 13 & 100 \\
\hline Parisuhde lopussa $(n=945)$ & 58 & 8 & 10 & 9 & 7 & 8 & 100 \\
\hline \multicolumn{8}{|l|}{ Yrityksen käyttökatteen (kannattavuuden) muuto } \\
\hline Stabiili $(n=2259)$ & 72 & 6 & 5 & 8 & 4 & 6 & 101 \\
\hline Vaihteleva $(n=1841)$ & 61 & 8 & 7 & 9 & 7 & 8 & 100 \\
\hline Kasvava $(n=2274)$ & 67 & 7 & 6 & 8 & 6 & 6 & 100 \\
\hline Laskeva $(n=2636)$ & 65 & 8 & 6 & 9 & 5 & 7 & 100 \\
\hline \multicolumn{8}{|l|}{ Toimipaikan henkilöstön määrä } \\
\hline $10-99(n=3484)$ & 63 & 9 & 6 & 9 & 6 & 7 & 100 \\
\hline $100-799(n=2909)$ & 68 & 6 & 7 & 8 & 5 & 7 & 101 \\
\hline $800-1746(n=2652)$ & 70 & 6 & 5 & 8 & 6 & 6 & 101 \\
\hline \multicolumn{8}{|l|}{ Toimiala v. 2007} \\
\hline Rahoitus, kiinteistöt, liike-elämän palvelut $(n=1203)$ & 60 & 9 & 7 & 9 & 5 & 10 & 100 \\
\hline Teollisuus $(n=3502)$ & 70 & 4 & 6 & 8 & 6 & 6 & 100 \\
\hline Rakentaminen, infrastruktuuri $(n=802)$ & 60 & 9 & 6 & 11 & 6 & 9 & 101 \\
\hline Tukku- ja vähittäiskauppa, korjaus ( $n=1687$ ) & 69 & 8 & 5 & 8 & 5 & 5 & 100 \\
\hline Majoitus ja ravitsemus $(n=276)$ & 68 & 8 & 6 & 5 & 4 & 8 & 99 \\
\hline Kuljetus, varastointi ja tietoliikenne $(n=1239)$ & 63 & 8 & 6 & 9 & 7 & 7 & 100 \\
\hline Yksityiset sosiaali-, terveys- ja koulutuspalvelut & 71 & 12 & 5 & 5 & 3 & 4 & 100 \\
\hline Muut (palvelut, järjestöt, alkutuotanto, $n=192$ ) & 63 & 11 & 6 & 8 & 4 & 7 & 99 \\
\hline \multicolumn{8}{|l|}{ Vaihtanut toimipaikkaa 2007 ja 2009 välillä } \\
\hline Ei, tai ei työllinen 2009 ( $n=6754)$ & 68 & 5 & 6 & 8 & 6 & 7 & 100 \\
\hline Kyllä (n=2395) & 60 & 15 & 5 & 9 & 5 & 5 & 99 \\
\hline \multicolumn{8}{|l|}{ Ollut työttömänä v. 2006} \\
\hline $\mathrm{Ei}(\mathrm{n}=8406)$ & 70 & 6 & 6 & 8 & 6 & 5 & 101 \\
\hline Kyllä (n=743) & 28 & 18 & 9 & 10 & 7 & 27 & 99 \\
\hline \multicolumn{8}{|c|}{ Ollut tai siirtynyt osittaiselle / kokoaikaiselle työkyvyttömyyseläkkeelle seuranta-aikana } \\
\hline $\operatorname{Ei}(n=8835)$ & 68 & 7 & 6 & 8 & 5 & 6 & 100 \\
\hline Kyllä (n=314) & 19 & 3 & 4 & 19 & 23 & 34 & 102 \\
\hline \multicolumn{8}{|l|}{ Opiskellut päätoimisesti seuranta-aikana } \\
\hline $\mathrm{Ei}(\mathrm{n}=8393)$ & 72 & 7 & 4 & 8 & 4 & 5 & 100 \\
\hline Kyllä (n=756) & 2 & 7 & 25 & 16 & 22 & 29 & 101 \\
\hline
\end{tabular}

Havainnot on painotettu todennäköisyydellä kuulua valittuun trajektoriryhmään. Tilastollisen testin (Khin neliö, F-testi) mukaan kaikki erot tilastollisesti merkitseviä ( $p=0.000$, pl. lapsen syntymä vuosina 2011-2015 p=0.027). 
Taulukko 2. Vuoden 2007 yksityisen sektorin työntekijöiden sijoittuminen työuraryhmiin (2007-2015) yksilö- ja perhe- sekä yritystekijöittäin, malli 3, multinomiaalinen regressio, RRR-kertoimet (Cl 95\%), $p \leq 0,05^{*}, p \leq 0,01 * *, p \leq 0,001 * * *$

\begin{tabular}{|c|c|c|c|c|c|c|}
\hline & $\begin{array}{l}\text { Vakaa } \\
\text { työura }\end{array}$ & $\begin{array}{l}\text { Nopeasti } \\
\text { vakautuva } \\
\text { työura }\end{array}$ & $\begin{array}{l}\text { Hitaasti } \\
\text { vakautuva } \\
\text { työura }\end{array}$ & $\begin{array}{l}\text { Hitaasti } \\
\text { heikkenevä } \\
\text { työura }\end{array}$ & $\begin{array}{l}\text { Heikkenevä } \\
\text { työura }\end{array}$ & $\begin{array}{l}\text { Nopeasti } \\
\text { heikkenevä } \\
\text { työura }\end{array}$ \\
\hline Sukupuoli (vrt. mies) nainen & vrt. & $1,51^{* * *}$ & $1,02 \mathrm{~ns}$ & $1,10 \mathrm{~ns}$ & $1,08 \mathrm{~ns}$ & $0,84 \mathrm{~ns}$ \\
\hline Ikä & & $0,97 * * *$ & $1,01 \mathrm{~ns}$ & $1,00 \mathrm{~ns}$ & $1,02 *$ & $1,02 \mathrm{~ns}$ \\
\hline Koulutusaste (vrt. perusaste) II aste & & $0,83 \mathrm{~ns}$ & $0,73 *$ & $0,82 \mathrm{~ns}$ & $0,67 * *$ & $0,46 * * *$ \\
\hline alin, alempi ka & & $0,72^{*}$ & $0,47 * * *$ & $0,59 * * *$ & $0,48 * * *$ & $0,24 * * *$ \\
\hline ylempi ka, tutkija & & $0,95 \mathrm{~ns}$ & $0,71 \mathrm{~ns}$ & $0,75 \mathrm{~ns}$ & $0,57 * *$ & $0,33 * * *$ \\
\hline Uusi tutkinto 2007-2015 (vrt. ei) kyllä & & $1,09 \mathrm{~ns}$ & $1,18 \mathrm{~ns}$ & $0,54 * * *$ & $0,84 \mathrm{~ns}$ & $0,78 \mathrm{~ns}$ \\
\hline Lasten Ikm v. 2006 (vrt. 0) 1-2 & & $1,18 \mathrm{~ns}$ & $0,90 \mathrm{~ns}$ & $0,82 \mathrm{~ns}$ & $0,79 \mathrm{~ns}$ & $0,57 * * *$ \\
\hline $3+$ & & $1,47 * *$ & $1,05 \mathrm{~ns}$ & $0,78 *$ & $0,71 *$ & $0,80 \mathrm{~ns}$ \\
\hline Lapsi syntyy v. 2007-2010 (vrt. ei) kyllä & & $0,90 \mathrm{~ns}$ & $0,94 \mathrm{~ns}$ & $1,02 \mathrm{~ns}$ & $1,01 \mathrm{~ns}$ & $0,67 \mathrm{~ns}$ \\
\hline - Lapsi syntyy X Nainen & & $2,78 * * *$ & $8,79 * * *$ & $1,60 \mathrm{~ns}$ & $2,02 *$ & $8,17 * * *$ \\
\hline Lapsi syntyy v. 2011-2015 (vrt. ei) kyllä & & $0,98 \mathrm{~ns}$ & $1,69 \mathrm{~ns}$ & $0,99 \mathrm{~ns}$ & $0,98 \mathrm{~ns}$ & $0,89 \mathrm{~ns}$ \\
\hline - Lapsi syntyy X Nainen & & $0,55 \mathrm{~ns}$ & $1,41 \mathrm{~ns}$ & $3,20 * * *$ & $4,01 * * *$ & $3,66 * * *$ \\
\hline Parisuhde: (vrt. on koko ajan) eroaa & & $1,22 \mathrm{~ns}$ & $1,59 * * *$ & $1,41 * *$ & $1,67 * *$ & $2,90 * * *$ \\
\hline ei koko aikana & & $0,91 \mathrm{~ns}$ & $1,38 \mathrm{~ns}$ & $1,28 *$ & $1,84 * * *$ & $3,50 * * *$ \\
\hline lopussa & & $1,10 \mathrm{~ns}$ & $2,37 * * *$ & $1,40 *$ & $1,98 * * *$ & $2,27 * * *$ \\
\hline Kannattavuus (vrt. stabiili) vaihteleva & vrt. & $1,56 * *$ & $1,73^{* * *}$ & $1,39 * *$ & $2,13 * * *$ & $1,91 * * *$ \\
\hline kasvava & & $1,23 \mathrm{~ns}$ & $1,29 \mathrm{~ns}$ & $1,12 \mathrm{~ns}$ & $1,47 *$ & $0,97 \mathrm{~ns}$ \\
\hline laskeva & & $1,40 * *$ & $1,30 \mathrm{~ns}$ & $1,26 *$ & $1,45 *$ & $1,46 * *$ \\
\hline Toimip. henkilöstö (vrt. 10-99) 100-799 & & $0,81 *$ & $1,10 \mathrm{~ns}$ & $0,88 \mathrm{~ns}$ & $0,86 \mathrm{~ns}$ & $1,08 \mathrm{~ns}$ \\
\hline $800-1746$ & & $0,68 * * *$ & $0,68 * *$ & $0,82 *$ & $0,96 \mathrm{~ns}$ & $0,87 \mathrm{~ns}$ \\
\hline Toimiala (vrt. rahoitus ym.) teollisuus & & $0,62 * * *$ & $0,82 \mathrm{~ns}$ & $0,81 \mathrm{~ns}$ & $1,18 \mathrm{~ns}$ & $0,55 * * *$ \\
\hline rakentaminen, infrastruktuuri & & $1,53 *$ & $1,27 \mathrm{~ns}$ & $1,41 *$ & $1,56 \mathrm{~ns}$ & $1,13 \mathrm{~ns}$ \\
\hline kauppa, korjaus & & $0,98 \mathrm{~ns}$ & $0,74 \mathrm{~ns}$ & $0,85 \mathrm{~ns}$ & $1,12 \mathrm{~ns}$ & $0,60 * *$ \\
\hline majoitus ja ravitsemus & & $0,75 \mathrm{~ns}$ & $0,86 \mathrm{~ns}$ & $0,55 *$ & $0,96 \mathrm{~ns}$ & $0,77 \mathrm{~ns}$ \\
\hline kuljetus, varastointi ja tietoliikenne & & $1,25 \mathrm{~ns}$ & $0,99 \mathrm{~ns}$ & $1,11 \mathrm{~ns}$ & $1,65 *$ & $0,86 \mathrm{~ns}$ \\
\hline yksityinen sote, koulutus & & $1,02 \mathrm{~ns}$ & $0,52 \mathrm{~ns}$ & $0,50 *$ & $0,60 \mathrm{~ns}$ & $0,31 * *$ \\
\hline muut & & $1,45 \mathrm{~ns}$ & $1,02 \mathrm{~ns}$ & $0,83 \mathrm{~ns}$ & $0,99 \mathrm{~ns}$ & $0,82 \mathrm{~ns}$ \\
\hline Eri toimipaikka 2007/2009 (vrt. ei) kyllä & & $3,24 * * *$ & $1,03 \mathrm{~ns}$ & $1,25 *$ & $1,08 \mathrm{~ns}$ & $0,74 *$ \\
\hline
\end{tabular}

Kontrolloitu: Työttömyys v. 2006, työkyvyttömyyseläke seuranta-aikana, päätoiminen opiskelu seuranta-aikana

Malli 0: Vain kontrollimuuttujat. $\mathrm{N}=9,149$, LR chi2(15)=2875,80, Prob $>$ chi2=0,000, Log likelihood $=-9135$, Selitysaste=13,6 \%

Malli 1: Kontrollimuuttujat + yksilö- ja perhetekijät. $N=9,149$, LR chi2(90)=3500, Prob > chi2=0,000, Log likelihood=-8823,

Selitysaste $=16,6 \%$. Selitysasteen ero malliin 0 nähden +3 prosenttiyksikköä

Malli 2: Kontrollimuuttujat + yritystekijät. $\mathrm{N}=9,003, \mathrm{LR}$ chi2 $(80)=3233$, Prob > chi2=0,000, Log likelihood=-8776, Selitysaste $=15,5 \%$.

Selitysasteen ero malliin 0 nähden $+1,9$ prosenttiyksikköä

Malli 3: Kontrollimuuttujat + yksilö- ja perhe- + yritystekijät. N=9,003, LR chi2(155)=3835, Prob > chi2=0,000, Log likelihood=-8475,

Selitysaste $=18,5 \%$. Selitysasteen ero malliin 0 nähden $+4,9$ prosenttiyksikköä.

mukaan osoitti, että urapolut eriytyvät nimenomaan naisilla. Naisilla lapsen syntymä seurannan alkupuolella ennakoi vakautuville urapoluille sijoittumista, mutta toisaalta seurannan loppujaksolla syntyvä lapsi yhdistyi heikkeneville työurapoluille siirtymiseen. Tästä huolimatta naisten työurat eivät todennäköisesti ole heikenneet pysyvästi vaan suurin osa heistä on palannut työhön myöhemmin, kuten seurannan alkupuolella syntyneen lapsen kohdalla jo ehtii tapahtua.

Toinen tärkeä havainto perhetekijöistä oli, että parisuhdetilanteella - yksin asumisella ja parisuhteen muutoksilla seuranta-aikana - oli voimakas yhteys muille kuin vakaalle työurapolulle sijoittumiseen, lukuun ottamatta nopeasti vakautuvan työuran ryhmään sijoittuneita. Ne, joilla oli koko ajan pysyvä parisuhde, sijoittuivat useimmin myös vakaimmalle työurapolulle. Sen sijaan kaikki muut parisuhdetilanteet yhdistyivät heikkeneviin työurapolkuihin, mikä on kriittinen havainto. Parisuhteiden ja työurapolkujen kehittymisen yhteydestä on varsin vähän aiempaa tutkimusta. Tutkimme tätä myös lisäämällä yhdysvaikutustermin sukupuolen kanssa, mutta se ei 
tuottanut merkittäviä havaintoja eli parisuhteen muutokset tai yksin asuminen ennakoivat sekä miesten että naisten heikompia työurapolkuja.

Aiemman tutkimuksen kautta tuttu on puolestaan havainto, että heikkeneville työurapoluille sijoittumiseen yhdistyi säännönmukaisesti alhaisempi koulutustaso (Peutere ym. 2017). Uuden tutkinnon suorittaminen seuranta-aikana ei sen sijaan - yllättäen - juuri muuttanut työurapoluille sijoittumista. Se kuitenkin vähensi hitaasti heikkenevään polkuryhmään sijoittumista. Myöskään ikä ja sukupuoli eivät erityisesti ennakoineet työurapoluille sijoittumista. Naiset sijoittuivat miehiä useammin kuitenkin nopeasti vakautuvan työuran polulle, kun taas ikävuosien lisääntyminen vähensi tähän nopeasti vakautuvan uran ryhmään sijoittumista. Kaikkiaan lasten syntymä naisilla ja parisuhdestatus niin miehillä kuin naisilla, yhdessä koulutustason kanssa, olivat merkittävimmät työurapoluille sijoittumista ennakoivat yksilö- ja perhetekijät.

\section{Yritysten kannattavuuden ja työurapolkujen yhteydet}

Toiseksi tutkimme, onko yrityksen toimialalla, koolla ja kannattavuudella (stabiili, vaihteleva, kasvava tai laskeva käyttökate vuosina 20052007) yhteyttä yksityisen sektorin työntekijöiden sijoittumiseen erilaisille työurapoluille. Tarkastelemme myös toimipaikan vaihdon työurayhteyksiä (taulukot 1 ja 2).

Toimialalla oli työurapoluille sijoittumisessa jonkin verran merkitystä, mutta se oli vaihtelevaa ja vaikeasti tulkittavissa. Kun vertailuryhmänä oli rahoituksen ja kiinteistöjen toimiala, etenkin teollisuustoimialalla työssä oleminen ennakoi sijoittumista vakaassa uraryhmässä olevia harvemmin yhtäältä nopeasti vakautuvan, mutta toisaalta myös nopeasti heikkenevän työuran ryhmiin. Toimipaikan suurin henkilöstömäärä puolestaan vähensi työntekijöiden sijoittumista etenkin molempiin vakautuvan sekä jonkin verran hitaasti heikkenevän työurapolun ryhmiin. Yritystekijöistä yrityksen kannattavuus ennusti työurapoluille sijoittumista. Taulukon 1 mukaan yrityksen käyttökatteen mukaan stabiilin kannattavuuden yrityksissä olleista 72 prosenttia sijoittui vakaalle työurapolulle. Vaihtelevan kannattavuuden yrityksissä vain 61 prosenttia, kasvavan kannattavuuden yrityksissä 67 prosenttia ja laskevan käyttökatteen yrityksissä 65 prosenttia henkilöistä sijoittui vakaalle työurapolulle. Stabiileissa yrityksissä vakaalla työuralla olevia oli siis suurin osuus. Monimuuttujatarkastelussa (taulukko 2) etenkin vaihtelevan kannattavuuden työpaikat ennakoivat myös vaihtelevimpia työurapolkuja. Tältä osin tilastolliset yhteydet osoittautuivat vahvoiksi. Jonkin verran työuria ennakoi myös yrityksen laskeva kannattavuus: se ennakoi sekä nopeasti vakautuvaan uraryhmään sijoittumista, todennäköisesti uuteen työpaikkaan siirtymisen kautta, että kaikkiin heikkeneviin uraryhmiin päätymistä.

Viimeisenä tarkastelimme toimipaikkaa vuosina 2007-2009 vaihtaneita. Eri toimi- eli työpaikkaan siirtyminen seurannan alkuvuosina yhdistyi nopeasti vakautuvaan työurapolkuryhmään ja vähensi hieman myös nopeasti heikkenevän työuran ryhmään sijoittumista. Toisaalta se lisäsi hieman päätymistä hitaasti heikkenevän työuran ryhmään. Työpaikan vaihtaminen tarkoittaa työntekijälle siis useammin myönteisiä kuin kielteisiä työuraseurauksia pitkällä aikavälillä. Tässä emme voi huomioida sitä, onko kyseessä vapaaehtoinen vai vastentahtoinen urasiirtymä.

\section{Johtopäätökset}

Tutkimuksemme on tuottanut uutta tietoa vuonna 2007 yksityisellä sektorilla työssä olleiden työurapoluista vuosien 2007-2015 taloudellisesti poikkeavissa olosuhteissa. Trajektorianalyysilla löytyi kuusi erilaista työurapolkua. Pitkästä talouden taantumasta huolimatta valtaosa (66 \%) yksityisen sektorin vuoden 2007 työntekijöistä sijoittui vakaalle työuralle eli he 
työskentelivätläpi seurantajakson keskimäärin 12 kuukautta kunakin vuonna. Hitaasti tai nopeasti vakautuville työurapoluille sijoittui vajaa kuudesosa (13\%) ja heikkeneville työurapoluille reilu viidennes (21\%) aineistomme henkilöistä. Seuranta-ajanjaksolle osuvasta taloudellisesta taantumasta huolimatta työurat olivat varsin vakaita. Tulos on linjassa eurooppalaisten keskimääräistä työurien vakautta koskevien tutkimustulosten kanssa (ks. Bachmann \& Felder 2018). Tutkimus rajautuu kuitenkin niihin, jotka olivat lähtötilanteessa työllisiä, emmekä tarkastelleet työttöminä tai työvoiman ulkopuolella olleiden kiinnittymistä työhön.

Toisena tutkimme, onko yksilö-, perhe- ja yritystekijöillä yhteys siihen, millaiselle työuralle sijoitutaan. Kaikkiaan erilaiset yksilö- ja perhetason tekijät ennakoivat hieman yritystekijöitä enemmän erilaisille työurapoluille sijoittumista. Perhetekijät - parisuhde ja lasten syntymä - yhdistyivät voimakkaasti muihin paitsi vakaisiin työurapolkuihin. Avo- tai avioerot, uuden puolison löytyminen ja yksin eläminen ennakoivat muita kuin vakaita työurapolkuja. Tulos vaatii lisätutkimusta, sillä parisuhde- ja työurapolkujen yhteisvaihtelua on tutkittu niukasti: Saksaa koskeneessa työuratarkastelussa (Biemann ym. 2012) naimisissa olo heikensi naisten työuria. Suomen maakonteksti on kuitenkin toinen ja naiset kiinnittyvät työmarkkinoille vahvasti. Yksin elävien työurapolkuja on tutkittu vielä vähemmän. Kuitenkin tiedetään, että yksin eläminen yhdistyy parisuhteessa eläviä useammin työttömyyteen etenkin miehillä, samoin kuin taloudelliseen niukkuuteen, mikä puolestaan on pitkittyessään hyvinvointiriski (Kauppinen ym. 2014).

Ei niinkään yllättäen, lapsen saaminen muutti olennaisesti naisten työurien kulkua (ks. myös Kuitto ym. 2019). Kun naisilla lapsen saanti yhdistyi eri vaiheissa seurantaa vakaista työurista eri tavoin poikkeaville poluille sijoittumiseen, ei lapsen syntymä juuri heiluttanut miesten (vakaampia) työuria. Lapsiperheiden vanhempien työllisyys on kaikkiaan erittäin korkeaa ja myös äidit useimmiten palaavat työhön perhevapaiden jälkeen (Peutere 2019; Salmi \& Närvi 2017); näin ollen ongelmana on hyvin epätasa-arvoinen perhevapaiden käyttö ja tätä epätasa-arvoa tuottava nykyinen perhevapaajärjestelmämme.

Kolmantena, yritystekijöistä tutkimme etenkin yritysten kannattavuuden (=käyttökatteen vaihtelun) ja henkilöstön työurien yhteyksiä. Yrityksiä oli tutkimuksessamme neljänlaisia: käyttökatteeltaan stabiileja, vaihtelevia, kasvavia ja laskevia. Kannattavuudeltaan vaihtelevissa yrityksissä työskentelevillä oli suurempi riski sijoittua niin vahvistuville kuin heikkeneville työurapoluille verrattuna niihin, jotka työskentelivät käyttökatteeltaan stabiileissa yrityksissä. Laskevan käyttökatteen yrityksissä työskentelevät kuuluivat jonkin verran niin nopeasti vakautuville kuin kaikille eri tavoin heikkeneville työurapoluille. Nopeasti vakautuvan uraryhmän tilanteessa on todennäköistä, että henkilö on vaihtanut toiseen työpaikkaan ja siirtynyt pois tällaisesta heikon kannattavuuden yrityksestä. Havaitsimme nimittäin, että toimipaikan vaihtaminen seurannan alkuvaiheessa ennakoi nopeasti vakautuvalle työurapolulle sijoittumista. Myös aiemmassa 1990-luvun lamaan kohdennetussa kotimaisessa tutkimuksessa työpaikan vaihtamisella on todettu olleen myönteinen yhteys vakaampaan työuraan (Peltola \& Soininen 2003, 15, 21-22). Tässä vaihtaminen ennakoi kuitenkin myös jonkin verran hitaasti ja nopeasti heikkeneviin urapolkuryhmiin sijoittumista. Työpaikan vaihtamiseen voi ajautua vastentahtoisesti, mikä todennäköisesti koskee matalasti koulutettuja. He sijoittuivat tässäkin tarkastelussa kaikille paitsi vakaille työurapoluille useammin kuin korkeasti koulutetut. Työmarkkinadynamiikan toista äärtä kuvaa se, että etenkin korkeasti koulutetut itse hakeutuvat uusiin työtehtäviin ja ikään kuin kilpailuttavat työmarkkina-arvoaan yritysten välillä. Muista yritystekijöistä henkilöstömäärältään suuremmalla toimipaikalla työskentely vakautti työuria, kun taas toimiala linkittyi työuriin vähemmän ja epäsystemaattisesti. 
Tulostemme perusteella yrityksen taloustilanteen vaihtelu on yksilölle riski (ks. myös Peutere ym. 2017), joskin yrityksen kannattavuus ennusti eri työurapoluille sijoittumista vähemmän kuin henkilön perhetilanne. Kuitenkin voimme päätellä, että vaikka kansantalouden näkökulmasta etenkin kasvuyrityksiä ja riskinottoa tarvitaan, työurien näkökulmasta lähinnä yritysten vakaa kannattavuus ja jatkaminen aiemmalla radallaan vakauttaa myös henkilöstön työuria. Aiemman tutkimustiedon perusteella tiedetään, että yrityksen kasvulla voi olla niin myönteisiä kuin kielteisiäkin vaikutuksia työpaikkojen syntymiseen (Maliranta \& Hurri 2017). Kannattavuuden kasvua voidaan tavoitella myös esimerkiksi irtisanomisten kautta.

Työurien vakaus ei ole kärsinyt aiempiin ajankohtiin nähden vuotta 2008 seuranneen finanssikriisin ja taantuman aikana. Tulos koskee niitä, jotka olivat ennen taantumaa työssä. Aiemmat tutkimustulokset kertovat, että työurien vakaus on kasvanut viimeisen runsaan kahden vuosikymmenen aikana (Peutere ym. 2017; Pyöriä ym. 2019; Rokkanen \& Uusitalo 2013; Soininen 2015; Sutela \& Lehto 2014; Sutela ym. 2019). Havainnot vastaavat esimerkiksi Tilastokeskuksen työolotutkimusten tuloksia. Vuoden 2013 työolotutkimukseen vastanneet palkansaajat olivat työskennelleet saman työnantajan palveluksessa keskimäärin 10,3 vuotta. Vuonna 1984 vastaava keskiarvo oli 8,3 vuotta. (Sutela \& Lehto 2014, 26-27.) Ammatin vaihtaminenkaan ei ole yleistynyt: neljä kymmenestä työolotutkimuksen vastaajasta ilmoitti työskennelleensä aina lähes samankaltaisessa ammatissa. Näin vastanneiden osuus on pysynyt lähes muuttumattomana vuodesta 1984 vuoteen 2018 saakka. (Sutela ym. 2019, 40.)

Oma kysymyksensä on, onko työurien vakauden kasvu pelkästään myönteinen ilmiö. Yksilön näkökulmasta työn vakaus on epäilemättä hyväksi, mutta toisaalta kansantalouden kannalta työmarkkinaliikkuvuuden heikkeneminen ei välttämättä ole hyvä asia. Näin voi olla esimerkiksi silloin, jos palkansaaja pysyy saman työnantajan palveluksessa, koska ei esimerkiksi laskusuhdanteessa uskalla vaihtaa työpaikkaa. Mikäli puolestaan määräaikaisissa työsuhteissa työskentelevien osuus palkansaajista vähenee, tämä voi tarkoittaa, ettei uusia työsuhteita ole syntynyt. Uusista työsuhteista noin puolet on nimittäin määräaikaisia (SVT 2019). Tässä työssäolokuukausilla tutkitut työurat eivät kuitenkaan yksi yhteen tarkoita vähäistä työmarkkinaliikkuvuutta, koska vakaasti työhön kiinnittyneistä henkilöistä neljännes vaihtoi toimipaikkaa vuosien 2007 ja 2009 välillä. Työkuukaudet voivat siis peittää alleen työpaikan vaihtoja ja eri työsuhteita samassa tai eri ammatissa.

Makroekonomisten tekijöiden, kuten heikon talouskasvun ja korkean työttömyyden ohella työmarkkinaliikkuvuutta saattavat heikentää sosiodemografiset muutokset, ennen kaikkea väestön ikääntyminen. Toisaalta vakaille työurille kiinnittyminen selittyy osin väestön koulutustason kohoamisella. Emme kuitenkaan voi arvioida, missä määrin löytämiämme työurapolkuja muokkasivat työvoiman käytön eri muodot, työelämän osaamisvaatimusten kasvu, digitalisaatio ja ammattien rakennemuutos (ks. Kauhanen 2017).

Aineistoomme ja samalla tutkimukseemme liittyy joitakin rajoituksia. Ensinnäkään tilinpäätöspaneeli ei sisällä kattavasti pienyritysten tietoja ja siksi tutkimuksesta on rajattu ulkopuolelle alle 10 henkilön yrityksissä työskentelevät. Organisaatioiden taloutta koskeva tieto on puutteellista myös julkisen sektorin osalta, minkä vuoksi rajauduimme yksityisyrityksiin. Myöskään tietoa työsuhteiden tyypeistä ei ollut käytettävissä. Vahvuutena on toisaalta laaja työntekijä- ja työnantajatietoja yhdistävä aineistokokonaisuus ja menetelmänä käytetty trajektorianalyysi, jonka on aiemmissa tutkimuksissa todettu soveltuvan hyvin erilaisten työurapolkujen ryhmittelyyn (esim. Jolkkonen ym. 2014, 507; Peutere ym. 2015, 25).

Jatkotutkimuksissa työmarkkinaliikkuvuutta olisi syytä analysoida pitkällä aikavä- 
lillä. Esimerkiksi urasiirtymiä toimipaikasta toiseen voisi tarkastella siitä näkökulmasta, ovatko ne vapaaehtoisia vai vastentahtoisia ja kenelle. Asiaa voisi arvioida yhtäältä sosioekonomisen aseman ja toisaalta tulokehityksen näkökulmista. Jatkotutkimuksissa olisi myös syytä ottaa huomioon erot yksityisen ja julkisen sektorin toimipaikkojen välillä, mitä emme ole voineet tässä tarkastella. Julkiseen sektoriin on kohdistettu voimakkaita säästötoimenpiteitä 1990-luvun lamasta alkaen, mutta samalla kunta- ja valtiosektori ovat toimineet tärkeinä työllistäjinä myös talouskriisien oloissa. Onko tässä tapahtumassa muutoksia 2020-luvulla? Lisäksi olisi tärkeää tarkentaa toimiala- ja ammattiryhmäkohtaista tutkimusta, ja edelleen arvioida, miten tukea ja edistää uusille koulutus- ja työurapoluille kiinnittymistä niissä ammattiryhmissä, joiden työtä teknologian kehitys myllertää. Myös parisuhdetilanteen muutosten, etenkin erojen tai toisaalta uuden parisuhteen löytymiseen liittyvien asuinpaikan vaihdosten, samoin kuin yksin elämisen, yhteyksiä työuriin olisi hyvä arvioida työ-, perhe- ja asuntopolitiikan näkökulmista.

\section{Viitteet}

1 Toimipaikkatason analyysi on perusteltua, kun tarkastelun kohteena on palkansaajien työmarkkinatilanne. Tilinpäätöstilastossa tilastoyksikkönä on itsenäinen liikeyritys.

2 Yritykset ja toimialat ovat erilaisia, ja yksittäiset taloudelliset tunnusluvut eivät kuvaa tyhjentävästi yritysten taloudellista tilannetta yli ajan. Tässä hyödyntämämme yrityksen kannattavuutta kuvaavan mittarin etuna on se, että yrityksen tilinpäätöksessä käyttökate ei ole yhtä helposti manipuloitavissa kuin muut liiketoiminnan tulosindikaattorit, koska se ei sisällä arvonalentumisia eikä investointeja.

3 Kokonaisaineistossa oli kaikkiaan 364125 yksityisen sektorin yritystä vuosina 2005-2009 ennen rajauksia.

\section{Kiitokset}

Kiitämme Työsuojelurahastoa projektien Pirstoutuvatko työurat? (117355) sekä Talouskriisit, työhyvinvointi ja työurat (114326) rahoituksesta.

\section{Kirjoittajat}

Katri-Maria Järvinen, YTT, tutkijatohtori, Tampereen yliopisto, sähköposti: katri-maria.jarvinen@tuni.fi Pasi Pyöriä, YTT, dos., yliopistonlehtori, Tampereen yliopisto, sähköposti: pasi.pyoria@tuni.fi Satu Ojala, YTT., dos., yliopistonlehtori, Tampereen yliopisto, sähköposti: satu.ojala@tuni.fi Liudmila Lipiäinen, FM, tutkija, Tampereen yliopisto, sähköposti: liudmila.lipiainen@tuni.fi

Tiina Saari, YTT, tutkijatohtori, Tampereen yliopisto, sähköposti: tiina.saari@tuni.fi

\section{Kirjallisuus}

Abowd, J. M. \& Kramarz, F. (1999) The analysis of labor markets using matched employer-employee data. Teoksessa O. Ashenfelter \& D. Card (toim.) Handbook of Labor Economics. Volume 3, Part B. Amsterdam: Elsevier, 2629-2710.

Aho, S. \& Mäkiaho, A. (2016) Krooninen työttömyys. Pitkään avoimien työmarkkinoiden ulkopuolella olleiden työttömien määrää ja rakennetta sekä työttömyyden dynamiikkaa Suomessa vuosina 2005-2013 selvittävä tutkimus. Valtioneuvoston selvitys- ja tutkimustoiminnan julkaisusarja 20/2016. Helsinki: Valtioneuvosto.

Aho, S., Virjo, I. \& Koponen, H. (2009) Ammatillinen liikkuvuus Suomessa 1989-2007. Valtioneuvoston kanslian julkaisusarja 5/2009. Helsinki: Valtioneuvosto.

Asplund, R. \& Vanhala, P. (2016) Korkeasti koulutettujen työmarkkinapolut - työllisyys, työttömyys ja syrjäytymisriski. Työ ja yrittäjyys 22/2016. Helsinki: Työ- ja elinkeinoministeriö. 
Bachmann, R. \& Felder, R. (2018) Job stability in Europe over the cycle. International Labour Review 157 (3), 481-51.

https://doi.org/10.1111/ilr.12117

Biemann, T., Zacher, H. \& Feldman, D. C. (2012) Career patterns: A twenty-year panel study. Journal of Vocational Behavior 81 (2), 159-170. https://doi.org/10.1016/j.jvb.2012.06.00

Busk, H., Holappa, V., Hyartt, M., Laamanen, J-P. \& Vainiomäki, J. (2020) Työvoiman ammatillisen liikkuvuuden osatekijät ja ohjauskeinot. Valtioneuvoston selvitys- ja tutkimustoiminnan julkaisusarja 2020:10. Helsinki: Valtioneuvosto.

Böckerman, P., Ilmakunnas, P. \& Johansson, E. (2011) Job security and employee well-being: Evidence from matched survey and register data. Labour Economics 18 (4), 547-554. https://doi.org/10.1016/j.labeco.2010.12.011

Collin, A. \& Young, R. A. (toim.) (2000) The Future of Career. Cambridge: Cambridge University Press. Davidsson, P. \& Wiklund, J. (2006) Conceptual and empirical challenges in the study of firm growth. Teoksessa P. Davidsson, F. Delmar \& J. Wiklund (toim.) Entrepreneurship and the Growth of Firms. Cheltenham: Edward Elgar, 39-61.

Eläketurvakeskus (2019) Työeläkeindikaattorit 2019. Eläketurvakeskuksen raportteja 05/2019. Helsinki: Eläketurvakeskus.

Eurofound (2015) Job Tenure in Turbulent Times. Luxemburg: Publications Office of the European Union. https://doi.org/10.2806/420768

Gerber, M., Wittekind, A., Grote, G. \& Staffelbach, B. (2009) Exploring types of career orientation: A latent class analysis approach. Journal of Vocational Behavior 75 (3), 303-318.

https://doi.org/10.1016/j.jvb.2009.04.003

Hetemäki, M. (2010) Nykyisen talouskriisin erityispiirteet ja talouspolitiikan mahdollisuudet. Työpoliittinen Aikakauskirja 53 (1), 15-25.

Hyytinen, A. \& Maliranta, M. (2008) When do employees leave their job for entrepreneurship? The Scandinavian Journal of Economics 110 (1), 1-21. https://doi.org/10.1111/ j.1467-9442.2008.00522.x

Ilmakunnas, S. (2010) Talouskriisi, työmarkkinat ja aktiivinen työvoimapolitiikka. Työpoliittinen Aikakauskirja 53 (1), 37-46.

Ilmakunnas, P. \& Maliranta, M. (2011) Suomen työpaikka- ja työntekijävirtojen käänteitä: toimialojen elinkaaret ja finanssikriisi. Työpoliittinen Aikakauskirja 54 (2), 6-23.
Ilmakunnas, P. \& Maliranta, M. (2016) How does the age structure of worker flows affect firm performance? Journal of Productivity Analysis 46 (1), 43-62.

https://doi.org/10.1007/s11123-016-0471-5

Jolkkonen, A., Koistinen, P., Kurvinen, A., Lipiäinen, L., Nummi, T. \& Virtanen, P. (2014) Kohtalokkaat olosuhteet ja yksilölliset tekijät: toimipaikan lakkauttamisen seurauksena työnsä menettäneiden kiinnittyminen työmarkkinoille. Kansantaloudellinen Aikakauskirja 110 (4), 492-515.

Järnefelt, N., Kautto, M., Nurminen, M. \& Salonen, J. (2013) Työurien pituuden kehitys 2000-luvulla. Eläketurvakeskuksen raportteja 01/2013. Helsinki: Eläketurvakeskus.

Järnefelt, N. (toim.) (2016) Työolot ja työurat - tutkimuksia työurien vakaudesta ja eläkkeelle siirtymisestä. Eläketurvakeskuksen tutkimuksia 08/2016. Helsinki: Eläketurvakeskus.

Kalleberg, A. L. \& Mouw, T. (2018) Occupations, organizations, and intergenerational career mobility. Annual Review of Sociology 44 (1), 283-303. https://doi.org/10.1146/annurev-soc-073117-041249

Kauhanen, M. (2017) Työllisyys ja työttömyys - Miten suomalaiset työmarkkinat ovat muuttuneet? Teoksessa H. Taimio (toim.) Tuotannon tekijät - palkansaajien Suomi 100 vuotta. Helsinki: Palkansaajien tutkimuslaitos, 152-189.

Kauppinen, T. M., Martelin, T., Hannikainen-Ingman, K. \& Virtala, E. (2014) Yksin asuvien hyvinvointi. Mitä tällä hetkellä tiedetään? Työpaperi 27/2014. Helsinki: Terveyden ja hyvinvoinnin laitos.

Kiljunen, M. \& Rikama, S. (2011) Sitä saa mitä tilaa: kasvuyritysten monet muodot hämmentävät. Tieto \& Trendit 7/2011, 10-11.

Koivunen, M., Lämsä, A-M. \& Heikkinen, S. (2012) Urasiirtymät muuttuvassa työelämässä - analyysi urasiirtymän käsitteestä. Working Paper 371. Jyväskylä: Jyväskylän yliopiston kauppakorkeakoulu.

Kuitto, K., Salonen, J. \& Helmdag, J. (2019) Gender inequalities in early career trajectories and parental leaves: Evidence from a Nordic welfare state. Social Sciences 8 (9), 1-16. https://doi.org/10.3390/socsci8090253

Maliranta, M. (2008) Kilpailun kehitys ja kannattavuuden mikrodynamiikka Suomen yrityssektorilla. Discussion Papers 1150. Helsinki: ETLA.

Maliranta, M. \& Hurri, P. (2017) Kasvuyritykset ja talouskasvu: empiirinen analyysi kasvuyritysten 
työllisyyden ja tuottavuuden dynamiikasta. Kansantaloudellinen Aikakauskirja 113 (1), 7-21.

Maliranta, M., Mankinen, R., Suni, P. \& Ylä-Anttila, P. (2011) Suhdanne- ja rakennekriisi yhtä aikaa? Toimiala- ja yritysrakenteen muutokset taantumassa. Keskusteluaiheita 1239. Helsinki: ETLA.

Myrskylä, P. (2014) Milloin työura alkaa ja loppuu? Tieto \& Trendit 2/2014, 26-29.

Nagin, D. (1999) Analyzing developmental trajectories: Semi-parametric, group-based approach. Psychological Methods 4 (2), 139-177. https://doi.org/10.I037//1082-989X.6.U8

Nagin, D. (2005) Group-Based Modeling of Development. Cambridge: Harvard University Press.

Ojala, S. \& Pyöriä, P. (2016) Vakautta vai epävarmuutta? Nuorten palkansaajien työuran alku 1980-luvulta 2010-luvulle. Teoksessa N. Järnefelt (toim.) Työolot ja työurat - tutkimuksia työurien vakaudesta ja eläkkeelle siirtymisestä. Eläketurvakeskuksen tutkimuksia 8/2016. Helsinki: Eläketurvakeskus, 25-49.

Peltola, M. \& Soininen, J. (2003) Lasku- ja kasvualojen työmarkkinat 1990-luvulla. VATT-keskustelualoitteita 318. Helsinki: Valtion taloudellinen tutkimuskeskus.

Peutere, L. (2019) Trajectories of Labour Market Attachment after Family and Work Related Transitions. Tampere University Dissertations 152. Tampere: Tampereen yliopisto.

Peutere, L., Vahtera, J., Kivimäki, M., Pentti, J. \& Virtanen, P. (2015) Job contract at birth of the first child as a predictor of women's labor market attachment: Trajectory analyses over 11 years. Nordic Journal of Working Life Studies 5 (1), 9-30. https://doi.org/10.19154/njwls.v5i1.4763

Peutere, L., Lipiäinen, L., Ojala, S., Järvinen, K-M., Pyöriä, P., Saari, T. \& Jokinen, E. (2017) Talouskriisit, työhyvinvointi ja työurat. Työsuojelurahaston tutkimushanke 2015-2017. Loppuraportti. Työelämän tutkimuskeskuksen työraportteja 94/2017. Tampere: Tampereen yliopisto.

Pyöriä, P. (toim.) (2017) Työelämän myytit ja todellisuus. Helsinki: Gaudeamus.

Pyöriä, P. \& Ojala, S. (2016) Prekaarin palkkatyön yleisyys: liioitellaanko työelämän epävarmuutta? Sosiologia 53 (1), 45-63.

Pyöriä, P., Lipiäinen, L. \& Järvinen, K-M. (2017) Yhä useampi palkansaaja on vakaalla työuralla. Tieto \& Trendit - Talous- ja hyvinvointikatsaus 3 (3), 48-53.
Pyöriä, P., Ojala, S. \& Nätti, J. (2019) Työelämän muutokset ajassamme. Teoksessa T. Heiskanen, S. Syvänen \& T. Rissanen (toim.) Mihin työelämä on menossa? - tutkimuksen näkökulmia. Tampere: Tampere University Press, 139-169.

Riekhoff, A-J. (2018) Retirement Trajectories in the Netherlands and Finland: Institutional Change, Inequalities, De-standardisation and Destabilisation. Studies 05/2018. Helsinki: Eläketurvakeskus.

Rokkanen, M. \& Uusitalo, R. (2013) Changes in job stability - Evidence from lifetime job histories. Finnish Economic Papers 26 (2), 36-55.

Salmi, M. \& Närvi, J. (2017) Johdanto. Teoksessa M. Salmi \& J. Närvi (toim.) Perhevapaat, talouskriisi ja sukupuolten tasa-arvo. Raportti 4/2017. Helsinki: Terveyden ja hyvinvoinnin laitos, 8-35.

Saloniemi, A., Salonen, J., Lipiäinen, L., Nummi, T. \& Virtanen, P. (2013) Opinnot ja työt. Kehityspolkuanalyysi ylemmän korkeakoulututkinnon suorittaneiden nuorten työurista. Yhteiskuntapolitiikka 78 (4), 402-415.

Soininen, T. (2015) Changing Expectations and Realities of Employment Stability: Longitudinal Analysis of Tenures in Finland. Joensuu: Itä-Suomen yliopisto.

Suomen virallinen tilasto (SVT 2018): Kansantalouden tilinpito. Bruttokansantuote (BKT) 19752018. Helsinki: Tilastokeskus. [online]. <URL: http://www.stat.fi/til/vtp/2018/ vtp_2018_2019-06-20_tau_001_fi.html>. Luettu 20.6.2019.

Suomen virallinen tilasto (SVT 2019): Työvoimatutkimus. Aikasarjatiedot 2009-2018, 2 Työllisyys ja työttömyys vuonna 2018. Helsinki: Tilastokeskus. [online]. <URL: http://www.stat.fi/til/tyti/2018/13/ tyti_2018_13_2019-04-11_kat_002_fi.html>. Luettu 25.11.2019.

Sutela, H. \& Lehto A-M. (2014) Työolojen muutokset 1977-2013. Helsinki: Tilastokeskus.

Sutela, H., Pärnänen, A. \& Keyriläinen, M. (2019) Digiajan työelämä - työolotutkimuksen tuloksia 1977-2018. Helsinki: Tilastokeskus.

Tilastokeskus (2017a) Aineistokuvaukset. [online]. <URL:https://tilastokeskus.fi/tup/mikroaineistot/aineistot.html>. Luettu 14.8.2017.

Tilastokeskus (2017b) Fleed-aineiston kuvaus. [online]. <URL: http://stat.fi/static/media/uploads/ tup/mikroaineistot/ya244_henkilot_2013.pdf>. Luettu 14.8.2017. 
Tilastokeskus (2019) Työlliset Työvoimatutkimuksen mukaan. Tilastokeskuksen Px-Web-tietokannat. [online]. <URL: https://pxnet2.stat.fi/PXWeb/pxweb/fi/StatFin/StatFin_tym_tyti_vv/ statfin_tyti_pxt_11qj.px/table/tableViewLayout1/>. Luettu: 20.6.2019.

Tolvanen, A. (2007) Latent Growth Mixture Modeling: A Simulation Study. Jyväskylä: Jyväskylän yliopisto.

Tornikoski, E., Saarakkala, M., Varamäki, E. \& Kohtamäki, M. (2011) Pk-yrityksen kasvutekijät ja kasvun hallinta: viitekehys kasvun haasteiden tunnistamiseksi. Liiketaloudellinen Aikakauskirja 1/2011, 11-32.
Valtioneuvoston kanslia (2017) Työurien jatkaminen vaatii yhteisöllisyyttä ja yhteistoiminnallisuutta. Valtioneuvoston selvitys- ja tutkimustoiminnan julkaisusarja 38/2017. Helsinki: Valtioneuvoston kanslia.

Valtioneuvoston kanslia (2019) Pääministeri Antti Rinteen hallituksen hallitusohjelma 6.6.2019. Osallistava ja osaava Suomi - sosiaalisesti, taloudellisesti ja ekologisesti kestävä yhteiskunta. Valtioneuvoston julkaisuja 23/ 2019. Helsinki: Valtioneuvoston kanslia.

Yritystutkimus (2017) Yritystutkimuksen tilinpäätösanalyysi. 10. korjattu laitos. Helsinki: Gaudeamus. 
Katri-Maria Järvinen, Pasi Pyöriä, Satu Ojala, Liudmila Lipiäinen \& Tiina Saari Career stability and recession: Private-sector employees' career trajectories, 2007-2015

This article examines the work careers of Finnish private-sector employees aged between 30 and 50 years old in the $2007-2015$ period, i.e. immediately before and after the 2008 financial crisis. Our key interest was in studying how individual and family antecedents as well as company-level measures - operating profit in particular - were associated with career stability. We used the Finnish Longitudinal Employer-Employee Data (FLEED-FOLK) and the Financial Statement Data Panel by Statistics Finland. First, we studied the employees' work careers using trajectory analysis, and second, we applied multinomial regression analysis to study connections between individual-, family-, and company-level variables and the employ- ees' career trajectory groups. In the analysis, six diverse career trajectories were found. Even though the financial crisis took place during the follow-up period, the majority (79\%) of private-sector employees had either a stable or stabilising work career. The key independent variables connected with more fragmented career trajectories were becoming a mother, the absence of a stable marital status, and the employer's less stable operating profit. For the majority, however, the results indicate the stability of work careers even in the context of the financial crisis and economic downturn after 2008. The findings concern those who were already employed before the crisis. 